\title{
IMPLEMENTASI PENDAYAGUNAAN ZAKAT PRODUKTIF TERHADAP PEMBERDAYAAN MUSTAHIQ PADA BADAN AMIL ZAKAT NASIONAL (BAZNAS) KABUPATEN LUMAJANG
}

\author{
Indra Hidayatullah \\ Institut Agama Islam Syarifuddin Lumajang \\ e-mail: Indra_hidayatullah@yahoo.co.id
}

\begin{abstract}
Zakat can be utilized for productive efforts in the context of handling the poor and improving the quality of the people. Along with Allah's commands to Muslims to pay zakat, zakat is one of the pillars of Islam which is not only of a vertical dimension, but also horizontal aspect. Zakat is an important worship in anticipating social inequality in its implementation. It is still largely traditional and does not pay attention to the welfare of the people, in fact the development of muslim is the majority population of this nation and it has a huge potential to be used as a source of funds from zakat. The result of research shows that utilization of productive zakat in the National Amil Zakat Agency (BAZNAS) of Lumajang Regency is to make people stand alone so that they can improve their standard of living and so as not to always depend on zakat funds. Mustahiq empowerment in the National Amil Zakat Agency (BAZNAS) Lumajang Regency is by running a productive zakat system for business capital assistance for the mustahiq and consumptive zakat system. Utilization of productive zakat funds is one of the processes carried out by the Lumajang National Amil Zakat Board (BAZNAS) to make the mustahiq be independent so that they can improve their standard of living and become muzakki as has become the vision of the National Amil Zakat Agency (BAZNAS) Regency Lumajang. The form of zakat fund utilization towards mustahiq empowerment at the National Amil Zakat Board (BAZNAS) of Lumajang Regency is divided into two empowerments, namely consumptive and productive empowerment. Consumptive empowerment is the provision of funds that can be directly consumed by mustahiq. While productive is the provision of capital in increasing business. Both in the form of funds and gifts in the form of work tools. The most effective thing in empowering the mustahiq is empowering by using productive zakat funds which have benefited a lot of mustahiq. Empowerment of zakat funds in relation is to convey part of the assets owned to a group called eight asnaf, namely the poor, poor, 'amil or administrators of zakat, muallaf, riqab (slaves), ghärimin, fï sabilillah and Ibn Sabil.
\end{abstract}

Keywords: Implementation, Utilization, Productive zakat, Mustahiq

\section{Pendahuluan}

Zakat adalah salah satu tiang pokok ajaran Islam yang sangat penting. Dengan zakat maka wajah kemasyarakatan dari ajaran Islam menjadi nyata. Sedangkan tanpa zakat, maka agama Islam akan nampak sebagai agama upacara. ${ }^{1}$

Adapun macam-macam zakat menurut garis besarnya terbagi dua, yaitu ${ }^{2}$ zakat mal

\footnotetext{
${ }^{1}$ Tim penyusun, Pedoman Zakat 9 Seri (Jakarta: Proyek Peningkatan Sarana Keagamaan Islam, Zakat dan Waqaf, 1997), 31.

${ }^{2}$ Muhammad Hasbi Ash Shiddieqy, Pedoman Zakat (Semarang: Pustaka Rizki Putra, 2006), 5.
} 
(harta), seperti emas, perak, binatang, tumbuh-tumbuhan (buah-buahan dan biji-bijian), barang perniagaan; dan zakat nafs, zakat jiwa yang disebut juga zakat al-fitrah (zakat yang diberikan berkenaan dengan selesainya mengerjakan puasa bulan Ramadlan.

Para ulama telah menjadikan zakât al-fitrah menjadi dua bagian, yaitu pertama adalah zakat harta yang nyata yang terang dilihat umum, seperti binatang, tumbuh-tumbuhan, buahbuahan, barang logam. Kedua adalah zakat harta-harta yang tidak nyata, yang dapat disembunyikan. Harta-harta yang tidak nyata itu, ialah emas, perak, rikaz dan barang perniagaan.

Dalam kitab-kitab fikih disebutkan bahwa harta kekayaan yang wajib dizakati atau dikeluarkan zakatnya dapat digolongkan menjadi beberapa kategori, yaitu ${ }^{3}$ emas, perak dan uang simpanan, barang yang diperdagangkan, hasil peternakan, hasil bumi, hasil tambang dan barang temuan.

Salah satu cara untuk menekan angka kemiskinan, masyarakat muslim ingin memanfaatkan dana zakat. Usaha Islam dalam menanggulangi problem kemiskinan ini, bukanlah suatu hal yang mengada-ada, temporer, setengah hati, atau bahkan hanya sekedar mencari perhatian. Pengurangan angka kemiskinan, bagi Islam, justru menjadi asas yang khas dan sendi-sendi yang kokoh. Hal ini dibuktikan dengan zakat yang telah dijadikan oleh Allah sebagai sumber jaminan hak-hak orang-orang fakir dan miskin itu sebagai bagian dari salah satu rukun Islam.

Untuk kasus di Indonesia yang secara demografi penduduknya mayoritas umat Islam, potensi zakat sangat besar harus diimbangi dengan pengelolaan zakat yang profesional pula. Sehingga zakat tersalurkan kepada mustahiq tidak bersifat konsumtif atau sesaat. Lembaga amil zakat jika memberikan zakat yang bersifat produktif, harus pula melakukan binaan dan dampingan kepada para mustahiq agar kegiatan usahanya dapat berjalan dengan baik. Selain sebagai modal usaha, penyaluran zakat produktif juga dapat berupa penyediaan sarana kesehatan gratis dan sekolah gratis untuk anak keluarga miskin. Tetapi sekali lagi, pendapatan keluarga miskin ini harus dilakukan dengan ketat agar zakat tidak terdistribusi kepada golongan yang tidak berhak. Penyaluran zakat produktif ini bukan tanpa kendala. Kendala utama adalah tidak diwajibkannya masyarakat menyalurkan zakatnya melalui lembaga amil zakat. Hal ini dikhawatirkan tidak ada kesadaran masyarakat yang memberikan zakat sendiri untuk memberikan zakat secara produktif.

Pengelolaan zakat yang profesional diharapkan distribusinya lebih produktif. Misalnya pemberian pinjaman modal, dalam rangka peningkatan perekonomian masyarakat. Zakat secara produktif ini bukan tanpa dasar. Zakat ini pernah terjadi di zaman Rasulullah. Dikemukakan dalam sebuah hadits riwayat Imam Muslim dari Salim bin Abdullah bin Umar dari ayahnya, bahwa Rasulullah telah memberikan zakat, lalu menyuruhnya untuk dikembalikan atau disedekahkan lagi.

Pada umumnya zakat yang diberikan kepada mereka bersifat konsumtif, yaitu untuk memenuhi kebutuhan sehari-hari. Hal ini kurang membantu mereka jangka panjang, karena uang atau barang kebutuhan sehari-hari yang akan diberikan akan segera habis dan mereka akan kembali hidup dalam keadaan fakir atau miskin. Pengelolaan zakat pada saat ini mengalami perkembangan yang sangat pesat, banyak sekali pendapat bahwa zakat yang

\footnotetext{
${ }^{3}$ Ahmad Rofiq, Komplikasi Zakat (Semarang: Balai Penelitian dan Pengembangan Agama Semarang, 2010$), 16$.
} 
disalurkan kepada mereka dapat bersifat konsumtif dan produktif.

Zakat dapat didayagunakan untuk usaha produktif dalam rangka penanganan fakir miskin dan peningkatan kualitas umat. ${ }^{4}$ Seiring dengan perintah Allah kepada umat Islam untuk membayarkan zakat, zakat merupakan salah satu rukun Islam yang tidak hanya berdimensi vertikal saja, tetapi sekaligus horizontal atau ibadah sosial. Zakat merupakan ibadah yang penting di dalam mengantisipasi kesenjangan sosial yang ada dalam pelaksanaannya itu sebagian besar masih bersifat tradisional dan kurang memperhatikan kesejahteraan umat. Pada kenyataannya perkembangan umat Islam merupakan penduduk mayoritas dari bangsa ini dan hal itu mempunyai potensi yang sangat besar untuk dijadikan sumber dana dari zakat.

Pelaksanaan zakat secara efektif adalah melalui badan amil zakat. Dalam Bab II Undang-Undang No. 23 tahun 2011 pasal 6, dikemukakan bahwa Badan Amil Zakat Nasional (BAZNAS) merupakan lembaga yang berwenang melakukan tugas pengelolaan zakat secara nasional. Maka zakat merupakan ibadah yang berdimensi horizontal kemanusiaan.

Dalam rangka meningkatkan daya guna dan hasil guna, zakat harus dikelola secara melembaga sesuai dengan syariat Islam, amānah, kemanfaatan, keadilan, kepastian hukum, terintegrasi dan akuntabel sehingga dapat meningkatkan efektifitas dan efisiensi pelayanan dalam pengelolaan zakat. Dalam upaya mencapai tujuan pengelolaan zakat, dibentuk Badan Amil Zakat Nasional, Badan Amil Zakat Nasional tingkat provinsi dan Badan Amil Zakat Nasional tingkat kabupaten atau kota. Badan Amil Zakat Nasional merupakan lembaga pemerintah non-struktural yang bersifat mandiri dan bertanggung jawab kepada Presiden melalui Menteri. Badan Amil Zakat Nasional merupakan lembaga yang berwenang melakukan tugas pengelolaan zakat secara nasional.

Dalam hal ini zakat produktif sangat berpengaruh terhadap taraf kehidupan para mustahiq. Karena para mustahiq bisa menggunakan keahlian mereka yang sempat terbengkalai karena tidak memiliki modal usaha yang cukup untuk mengunakan keahlian mereka. Dengan adanya zakat produktif ini juga, para mustahiq yang sebelumnya hanya menjadi seorang penerima zakat saja, maka dengan adanya bantuan dana dari zakat produktif ini, para mustahiq pun bisa menjadi muzakki. Pertanyaan yang akan dijawab dalam penelitian adalah bagaimana pendayagunaan zakat produktif di Badan Amil Zakat Nasional (BAZNAS) Kabupaten Lumajang, dan bagaimana pemberdayaan mustahiq di Badan Amil Zakat Nasional (BAZNAS) Kabupaten Lumajang?

\section{Metode Penelitian}

Penelitian ini merupakan penelitian kualitatif, artinya penelitian yang menggunakan data informasi berbagai macam teori yang diperoleh. Sejalan dengan definisi tersebut, Bogdan dan Taylor mendefinisikan metode kualitatif sebagai prosedur penelitian yang menghasilkan data deskriptif berupa kata-kata tertulis atau lisan dari orang-orang dan perilaku yang dapat diamati. $^{5}$

\footnotetext{
${ }^{4}$ Tim Penyusun, Himpunan Peraturan Perundangan Pengelolaan Zakat (Lumajang: BAZNAS Kabupaten Lumajang, t.th.), 15.

${ }^{5}$ Lexy J. Moleong, Metode Penelitian Kualitatif (Bandung: Remaja Rosda Karya, 2011), 04.
} 
Penelitian kualitatif menghabiskan waktu yang cukup lama dalam tata situasi (setting) penelitian. Dalam penelitian kualitatif peneliti menggunakan alat bantu dalam pengumpulan data. Data-data yang dikumpulkan perlu ditunjang oleh pemahaman yang mendalam tentang makna data-data yang diperoleh. Kemudian materi direkam dan dikaji ulang dengan melibatkan wawasan penulis sebagai instrumen kunci untuk menganalisisnya.

Adapun jenis penelitian yang digunakan dalam penelitian ini menggunakan penelitian yang bersifat deskriptif, yaitu penelitian yang berusaha untuk menggambarkan implementasi pendayagunaan zakat produktif terhadap pemberdayaan mustahiq. Tujuan dalam penelitian ini agar mendapatkan data-data tertulis maupun lisan dari sumber-sumber tertentu sehingga terungkap hasil penelitian mengenai pendayagunaan zakat produktif terhadap pemberdayaan mustahiq pada Badan Amil Zakat Nasional (BAZNAS) Kabupaten Lumajang.

Sedangkan untuk teknik pengumpulan data, penulis menggunakan metode 1) wawancara yang digunakan untuk medapatkan informasi tentang pendayagunaan zakat produktif dan pemberdayaan mustahiq. Dalam hal ini penulis menggunakan wawancara terstruktur dan tidak terstruktur; 2) observasi yang digunakan untuk mengetahui obyek secara langsung khususnya mengenai peranan pendayagunaan zakat produktif terhadap pemberdayan mustahiq pada Badan Amil Zakat Nasional (BAZNAS) Kabupaten Lumajang; 3) dokumentasi yang digunakan untuk memperoleh data-data tertulis, seperti sejarah berdirinya Badan Amil Zakat Nasional (BAZNAS) Kabupaten Lumajang, struktur organisasi Badan Amil Zakat Nasional (BAZNAS) Kabupaten Lumajang dan lain sebagainya

Untuk analisis data yang digunakan dalam penelitian ini adalah menggunakan metode dari Milles dan Huberman, yaitu 1) reduksi data, yaitu proses pemilihan, pemusatan perhatian pada penyederhanaan, pengabstrakan dan transformasi data kasar yang muncul dari catatancatatan tertulis di lapangan; 2) penyajian data, yaitu sebagai sekumpulan informasi yang tersusun, sehingga memberi kemungkinan adanya penarikan kesimpulan dan pengambilan tindakan; dan 3) penarikan kesimpulan yang merupakan kegiatan untuk menarik makna dari data yang ditampilkan.

\section{Konsep Zakat}

Zakat ialah nama atau sebutan dari suatu hak Allah yang dikeluarkan seseorang kepada fakir miskin. Dinamakan zakat, karena di dalamnya terkandung harapan untuk beroleh berkat, membersihkan jiwa dan memupuknya dengan berbagai kebajikan ${ }^{6}$.

Mayoritas ulama sependapat bahwa yang menjadi objek zakat adalah segala harta yang mempunyai nilai ekonomi dan potensial untuk berkembang. Pengumpulan zakat tidak bisa dilaksanakan karena adanya kebutuhan negara serta maslahat komunitas. Zakat merupakan jenis harta khusus yang wajib diserahkan kepada lembaga amil zakat atau bayt al-mal setelah memenuhi nișab (masa tertentu).

Para ulama sepakat bahwa yang diwajibkan berzakat adalah seorang muslim dewasa, berakal sehat, merdeka serta mempunyai harta atau kekayaan yang cukup nișab (sejumlah harta yang telah cukup jumlahnya untuk dikeluarkan zakatnya) dan memenuhi haul (telah cukup waktu untuk mengeluarkan zakat yang biasanya kekayaan itu telah dimilikinya dalam

\footnotetext{
${ }^{6}$ Sayyid Sabiq, Fikih Sunnah, Terj. Mahyudin Syaf (Bandung: Al Ma’arif, t.th.), 5.
} 
waktu satu tahun). Kekayaan yang biasanya wajib dizakati karena sudah memenuhi haul antara lain emas, perak, barang dagangan, ternak sapi, kerbau, kambing dan unta. Tetapi ada juga kekayaan yang wajib dizakati tanpa menunggu jangka waktu pemilikan satu tahun, seperti hasil bumi, begitu dihasilkan atau panen maka dikeluarkan zakatnya.

Adapun syarat-syarat kekayaan yang wajib dizakati adalah:

1. Milik penuh, bahwa kekayaan itu harus berada dibawah kontrol dan kekuasaannya, atau seperti yang dinyatakan ahli fikih bahwa kekayaan itu harus berada ditangannya, tidak tersangkut di dalamnya hak milik orang lain, dapat ia pergunakan dan faedahnya dapat dinikmatinya.

2. Berkembang, maksudnya kekayaan itu memberikan keuntungan atau pendapatan.

3. Cukup satu nișab, yaitu jumlah harta tertentu yang sudah cukup jumlahnya untuk dikeluarkan zakatnya.

4. Bebas dari hutang, maksudnya bila pemilik kekayaan itu mempunyai hutang yang menghabiskan atau mengurangi jumlah kepemilikan sehingga kekayaan itu tidak sampai satu nișab.

5. Berlalu satu tahun, adalah kekayaan yang berada di tangan pemiliknya sudah berlalu masanya satu tahun. Persyaratan satu tahun ini hanya untuk ternak, uang dan harta benda dagang. Tetapi untuk hasil pertanian, buah-buahan, madu, harta karun dan sejenisnya tidaklah dipersyaratkan untuk menunggu dalam waktu satu tahun.

Secara substansial, zakat digolongkan menjadi empat jenis, yaitu: ${ }^{7}$

1. Zakat fitrah untuk setiap pribadi (badan)

Zakat ini merupakan zakat yang diwajibkan untuk setiap pribadi muslim.

2. Zakat kekayaan

Ada dua jenis barang kekayaan dikenakan wajib zakat atas dasar besarnya nilai kekayaan tersebut, yaitu zakat uang berupa emas dan perak dan zakat ternak.

3. Zakat penghasilan

Jenis barang dikenakan wajib zakat atas dasar besarnya penghasilan mengandung makna perhitungan zakat atas dasar produksi dikalikan harganya, kemudian besarnya penghasilan kotor dikurangi biaya-biaya langsung maupun tidak langsung, upah dan gaji karena jabatan profesi tertentu.

4. Zakat barang temuan

Zakat barang temuan merupakan bentuk pendapatan yang diperoleh tanpa biaya. Besarnya zakat adalah $20 \%$.

Untuk orang-orang yang terkena wajib zakat harus memenuhi syarat-syarat tertentu, yaitu merdeka, Islam, baligh dan berakal, harta tersebut memang harta yang wajib dizakati, telah mencapai niṣab, milik penuh, telah mencapai haul, tidak memiliki hutang, harta kekayaannya melebihi kebutuhan dasar atau pokok, dan harta tersebut berkembang. ${ }^{8}$

Di dalam Islam sendiri, zakat memiliki lima prinsip, yaitu prinsip keyakinan keagamaan; prinsip kemerataan dan keadilan; prinsip penalaran dan kebebasan; prinsip produktifitas dan kematangan; dan prinsip etika dan kewajaran. ${ }^{9}$

\footnotetext{
${ }^{7}$ Sahri Muhammad, Mekanisme Zakat dan Permodalan Masyarakat Miskin (t.tp.: Bahtera Press, 2006), 32.

${ }^{8}$ Fakhruddin, Fiqih dan Manajemen Zakat di Indonesia (Yogyakarta: UIN-Malang Press, 2008), 33.

${ }^{9}$ Gustian Djuanda dkk, Pelaporan Zakat Pengurang Pajak Penghasilan (Jakarta: Rajawali Pers, 2006), 14.
} 


\section{Zakat Produktif}

Zakat produktif adalah pendayagunaan secara produktif yang pemahamannya lebih kepada bagaimana cara atau metode menyampaikan dana zakat kepada sasaran dalam pengertian yang lebih luas, sesuai dengan ruh dan tujuan syara' ${ }^{10}$

Pendayagunaan zakat harus berdampak positif bagi mustahiq, baik secara ekonomi maupun sosial. Dari sisi ekonomi, mustahiq dituntut benar-benar dapat mandiri dan hidup secara layak sedangkan dari sisi sosial, mustahiq dituntut dapat hidup sejajar dengan masyarakat yang lain. Hal ini berarti, zakat tidak hanya didistribusikan untuk hal-hal yang konsumtif saja dan hanya bersifat edukatif.

Kelemahan utama orang miskin serta usaha kecil yang dikerjakannya sesungguhnya tidak semata-mata pada kurangnya permodalan, tetapi lebih pada sikap mental dan kesiapan manajemen usaha. Untuk itu, zakat usaha produktif pada tahap awal harus mampu mendidik mustahiq sehingga benar-benar siap untuk berubah. Karena tidak mungkin kemiskinan itu dapat berubah kecuali dimulai dari perubahan mental. Inilah yang disebut peran pemberdayaan.

'Amil dengan segala kesiapannya merupakan lembaga pemberdayaan dalam arti yang luas. 'Amil juga harus berperan sebagai agen perubahan dan pemberdayaan. Zakat yang dapat dihimpun dalam jangka panjang harus dapat memberdayakan mustahiq sampai pada dataran pengembangan usaha. Program-program yang bersifat jangka konsumtif ini hanya berfungsi sebagai stimulan atau rangsangan dan berjangka pendek, sedangkan program pemberdayaan ini harus diutamakan. Makna pemberdayaan dalam arti yang luas ialah memandirikan mitra, sehingga mitra dalam hal ini mustahiq tidak selamanya tergantung pada 'amil.

Dalam hal zakat untuk usaha yang produktif, maka pelaksanaannya harus memenuhi ketentuan sebagaimana diatur dalam pasal 29 Undang-Undang No. 38 tahun 1999 sebagai berikut $^{11}$ :

1. Melakukan studi kelayakan

Yang dimaksud studi kelayakan yaitu upaya untuk memperoleh keyakinan bahwa usaha yang dibiayai dari dana zakat benar-benar dapat berkembang dan dapat mengembalikan pinjamannya. Hasil dari studi kelayakan ini harus menunjukkan data yang jelas tentang calon mustahiq; kebutuhan pinjaman yang pasti; kemampuan pengembalian dengan jangka waktu yang jelas; jumlah bagi hasil yang mampu dibayarkan; dan peruntukan atau lokasi pinjaman yang jelas.

2. Menetapkan jenis usaha produktif

Langkah ini sesungguhnya dapat berupa dua macam, yaitu pertama, jika mustahiq belum memiliki usaha, maka tugas 'ámil mendorong dan mengarahkan sehingga mustahiq dapat membuka usaha yang layak. Sedapat mungkin dihindari kesan pemaksaan apalagi menggurui, karena akan berdampak kurang positif. Kedua, jika mustahiq telah memiliki usaha tetapi tidak berkembang, maka tugas 'amil menganalisis usahanya. Hasil analisis dapat menunjukkan dua kemungkinan. Kemungkinan pertama, usahanya dapat dikembangkan dan kedua, usahanya sulit untuk berkembang, sehingga perlu ditemukan

\footnotetext{
${ }^{10}$ Asrifin An Nakhrawie, Sucikan Hati dan Bertambah Kaya Bersama Zakat (Jakarta: Delta Prima Press, 2011), 163.

${ }^{11}$ Muhammad Ridwan, Manajemen Baitul Maal Wa Tamwil (BMT) (Yogyakarta: UII Press, 2004), 217-219.
} 
alternatif sebagai penggantinya. Pada kemungkinan pertama, tugas 'ámil yaitu memotivasi dan menemukan langkah-langkah pengembangannya, namun pada kemungkinan kedua, maka tugas 'ámil meyakinkan bahwa usahanya berprospek tidak baik dan mencarikan usaha penggantinya.

3. Melakukan bimbingan dan penyuluhan

Membimbing dan memberikan penyuluhan ini merupakan tugas untuk menjaga agar usahanya tetap berjalan dan berkembang serta mengamankan dana zakatnya. Tanpa fungsi ini, dikhawatirkan dana zakat akan disalahgunakan untuk kepentingan yang tidak sesuai dengan usulannya. Fungsi ini selayaknya diperankan konsultan bagi perusahaan. Untuk mengefektifkan fungsi ini, mustahiq dapat dibuat kelompok, sehingga lebih mudah dalam pengarahan dan penyuluhan.

4. Melakukan pemantauan, pengendalian dan pengawasan

Tugas ini menjadi sulit dilakukan manakala mustahiq, belum menyadari pentingnya pengendalian. Meskipun 'amil bertanggung jawab atas pemantauan dan pengawasannya, namun yang terpenting sesungguhnya menciptakan kesadaran pengawasan oleh mustahiq sendiri. Artinya mendidik mustahiq untuk bertanggung jawab terhadap segala keputusan bisnis dan perilaku sosialnya.

5. Mengadakan evaluasi

Evaluasi dilakukan untuk mendapatkan data, bahwa usaha yang dijalankan dapat berkembang sesuai rencana, serta dana yang disalurkan benar-benar tepat sasaran. Program ini dapat dilakukan bersama-sama dengan mustahiq. Diharapkan 'ámil hanya akan memfasilitasi, sehingga mustahiq yang akan melakukan evaluasi sendiri.

6. Membuat pelaporan

Pelaporan merupakan wujud transparansi dan akuntabilias lembaga 'amil zakat. Hasil pendayagunaan zakat untuk usaha produktif harus dapat dilaporkan secara terbuka kepada masyarakat termasuk pemerintah dan muzakki $>^{-}$sendiri. Pelaporan dapat bersifat kuantitatif dan juga kualitatif ${ }^{12}$.

Maksud pengertian zakat produktif adalah dana yang akan diberikan kepada mustahiq harus diserahkan dahulu kepada mustahiq, baru kemudian mustahiq ditawari untuk ikut berpartisipasi dalam usaha atau tidak. Bila mustahiq menyatakan tidak mau ikut dalam usaha, maka pihak 'ámil tidak boleh memeaksakan kehendak. Namun, bila si mustahiq menyatakan bersedia ikut dalam usaha, maka hak itu adalah hak mustahiq dan kepemilikannya adalah atas nama mustahiq. ${ }^{13}$

Pola distribusi zakat produktif yang dikembangkan pada umumnya mengambil skema qard al-hasan. Yaitu salah satu bentuk pinjaman yang menetapkan tidak adanya tingkat pengembalian tertentu dari pokok pinjaman. Namun bila ternyata si peminjam dana tersebut tidak mampu mengembalikan pokok tersebut, maka hukum zakat mengidentifikasikan bahwa si peminjam tersebut tidak dapat dituntut atas ketidakmampuannya. Karena dana tersebut adalah hak mereka. ${ }^{14}$

\footnotetext{
12 Ibid.

${ }^{13}$ Umrotul Khasanah, Manajemen Zakat, 208.

${ }^{14}$ M. Arief Mufraini, Akuntansi dan Menejemen Zakat (Jakarta: Kencana Prenada Media Group, 2006), 165.
} 
Ada juga penyaluran dana zakat produktif yang memanfaatkan skema mudärabah. Lembaga LAZIS membuat inovasi dimana lembaga 'amil tersebut berlaku sebagai investor (mudāarib) yang menginvestasikan dana hasil pengumpulan ZIS kepada mustahiq sendiri, sebagai peminjam dana yang dituntut tingkat pengembalian tertentu khusus bagi para pedagang kecil di pasar tradisional dengan angsuran pinjaman dan tingkat pengembalian dibayarkan setiap hari. Antara pola mudärabah dan qard al-hasan hampir sama. Namun yang membedakan adalah apabila usaha tersebut untung, maka mustahiq mengambil sejumlah persen laba dan sejumlah persen dikembalikan kepada BAZ berikut modalnya. BAZ menerima modal kembali berikut persentase keuntungan usaha. ${ }^{15}$

Adapun langkah-langkah pendistribusian zakat produktif tersebut sebagai berikut ${ }^{16}$ :

1. Pendataan yang akurat sehingga yang menerima benar-benar orang yang tepat.

2. Pengelompokan peserta ke dalam kelompok kecil, homogen baik dari sisi gender, pendidikan, ekonomi dan usia dan kemudian dipilih ketua kelompok, diberi pembimbing dan pelatih.

3. Pemberian pelatihan dasar, pada pendidikan dalam pelatihan harus berfokus untuk melahirkan pembuatan usaha produktif, menejemen usaha, pengelolaan keuangan usaha dan lain-lain. Pada pelatihan ini juga diberi penguatan secara agama sehingga melahirkan anggota yang berkarakter dan bertanggung jawab.

4. Pemberian dana, dana diberikan setelah materi tercapai, dan peserta dirasa telah dapat menerima materi dengan baik. Usaha yang telah direncanakan pun dapat diambil. Anggota akan dibimbing oleh pembimbing dan mentor secara intensif sampai anggota tersebut mandiri untuk menjalankan usaha sendiri.

Pengelolaan zakat merupakan suatu kegiatan perencanaan, pengorganisasian, pelaksanaan sekaligus pengawasan terhadap pengumpulan dan pendistribusian serta pendayagunaan zakat. Oleh karena itu untuk optimalisasi pendayagunaan zakat diperlukan pengelolaan zakat oleh lembaga 'amil zakat yang profesional dan mampu mengelola zakat secara tepat sasaran.

Pengelolaan zakat melalui lembaga 'amil didasarkan beberapa pertimbangan: ${ }^{17}$

1. Untuk menjamin kepastian dan disiplin pembayaran zakat.

2. Menjaga perasaan rendah diri para mustahiq apabila berhadapan langsung untuk menerima haknya dari muzakki.

3. Untuk mencapai efesiensi, efektifitas dan sasaran yang tepat dalam menggunakan harta zakat menurut skala prioritas yang ada disuatu tempat misalnya apakah disalurkan dalam bentuk konsumtif ataukah dalam bentuk produktif untuk meningkatkan kegiatan usaha para mustahiq.

4. Untuk memperlihatkan syiar dan semangat penyelenggaraan negara dan pemerintahan yang islami. Sebaliknya jika penyelenggaraan zakat itu begitu saja diserahkan kepada para muzakki, maka nasib dan hak-hak orang miskin dan para mustahiq lainnya terhadap orang-orang kaya tidak memperoleh jaminan yang pasti.

Pada prinsipnya pendayagunaan hasil pengumpulan zakat untuk mustahiq dilakukan

\footnotetext{
15 Ibid., 168.

${ }^{16}$ Ibid., 169.

${ }^{17}$ Ibid.
} 
berdasarkan persyaratan berikut, yaitu ${ }^{18}$ hasil pendapatan dan penelitian kebenaran mustahiq delapan așnáf; mendahulukan orang-orang yang paling tidak berdaya memenuhi kebutuhan dasar secara ekonomi dan sangat memerlukan bantuan; mendahulukan mustahiq dalam wilayahnya masing-masing. Sedangkan untuk pendayagunaan hasil pengumpulan zakat secara produktif dilakukan setelah terpenuhinya poin-poin di atas.

Adapun prosedur pendayagunaan pengumpulan hasil zakat untuk produktif berdasarkan ${ }^{19}$ pada melakukan studi kelayakan; menetapkan jenis usaha produktif; melakukan bimbingan dan penyuluhan; melakukan pemantauan, pengendalian dan pengawasan; mengadakan evaluasi; dan membuat pelaporan.

Sistem pendistribusian zakat yang dilakukan haruslah mampu mengangkat dan meningkatkan taraf hidup umat Islam, terutama para penyandang sosial. Baik LAZ maupun BAZ memiliki misi mewujudkan kesejahteraan masyarakat dan keadilan sosial. Banyaknya BAZ dan LAZ yang lahir tentu akan mendorong penghimpunan dana zakat masyarakat. Ini tentu baik karena semakin banyak dana zakat yang dihimpun, makin banyak pula dana untuk kepentingan sosial.

Pendayagunaan hasil pengumpulan zakat dapat dilakukan dalam dua pola, yaitu pola produktif dan pola konsumtif. Para 'àmil zakat di harapkan mampu melakukan pembagian porsi hasil pengumpulan zakat, misalnya $60 \%$ dan $40 \%$ untuk zakat produktif. Program penyaluran hasil pengumpulan zakat secara konsumtif bisa dilakukan untuk memenuhi kebutuhan dasar ekonomi para mustahiq melalui pemberian langsung, maupun melalui lembaga-lembaga yang mengelola fakir miskin, panti asuhan maupun tempat-tempat ibadah yang mendistribusikan zakat kepada masyarakat. Sedangkan program penyaluran hasil pengumpulan zakat secara produktif dapat dilakukan melalui program bantuan pengusaha lemah, pendidikan gratis dalam bentuk beasiswa dan pelayanan kesehatan gratis.

\section{Pendayagunaan Zakat}

Pendayagunaan yang efektif ialah manfaatnya sesuai dengan tujuan dan sasaran sebagaimana dalam al-Quran:

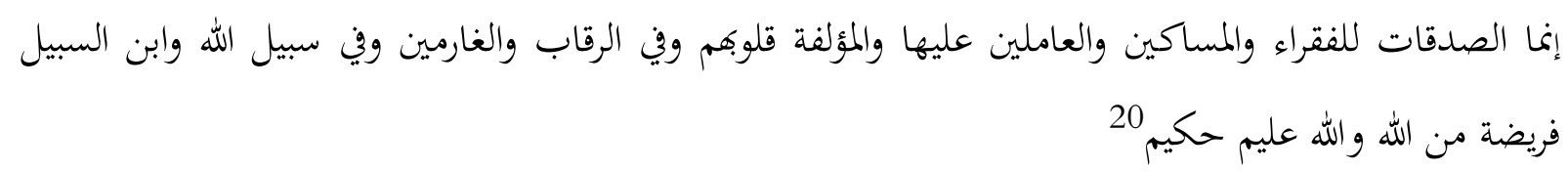

"Sesungguhnya zakat-zakat itu, hanyalah untuk orang fakir, orang-orang miskin, pengurus-pengurus zakat, para muallaf yang dibujuk hatinya, untuk memerdekakan budak, orang-orang yang berhutang, untuk jalan Allah dan untuk mereka yang sedang diperjalanan, sebagai suatu ketetapan yang diwajibkan Allah dan Allah maha mengetahui dan bijaksana."

\footnotetext{
18 Ibid.

19 Ibid.

${ }^{20}$ al-Quran, 9: 60.
} 
Arti dari pendayagunaan zakat adalah bagaimana menjadikan zakat agar berfungsi sebagai amal ibadah dan juga konsep sosial. Dalam hal ini, pemanfaatan zakat dapat digolongkan dalam empat bentuk, yaitu: ${ }^{21}$

1. Bersifat konsumtif tradisional, yaitu zakat dibagikan kepada mustahiq untuk dibagikan langsung, seperti zakât al-fitrah yang diberikan kepada fakir miskin untuk memenuhi kebutuhan sehari-hari atau zakät al-mal (harta) yang dibagikan habis langsung kepada mustahiq.

2. Konsumtif kreatif, yaitu zakat yang diwujudkan dalam bentuk lain dari barangnya semula, seperti diberikan dalam bentuk alat-alat sekolah, beasiswa, cangkul, gerabah dan sebagainya.

3. Produktif tradisional, di mana zakat diberikan dalam bentuk barang-barang yang produktif, seperti kambing, sapi, alat cukur, pertukangan, mesin jahit dan lain-lain. Pemberian dalam bentuk ini akan dapat menciptakan suatu usaha untuk memberikan lapangan kerja baru bagi fakir miskin.

4. Produktif kreatif, yaitu zakat diwujudkan dalam bentuk permodalan bergulir baik untuk permodalan proyek sosial atau untuk membantu atau menambah modal pedagang atau pengusaha kecil. Pemanfaatan zakat dalam bentuk ketiga dan keempat itu adalah yang mendekati pada arti pendayagunaan, yang harus kita kembangkan, sehingga makna syariat zakat baik dari segi fungsi ibadah maupun sosialnya dapat tercapai seperti yang diharapkan.

\section{Pemberdayaan Mustahiq}

Pemberdayaan pada kaitannya dengan penyampaian kepemilikan harta zakat kepada mereka yang berhak terbagi ke empat bagian, yaitu: ${ }^{22}$

1. Pemberdayaan sebagian dari kelompok yang berhak akan harta zakat, misalnya fakir miskin, yaitu dengan memberikan harta zakat kepada mereka sehinga dapat memenuhi kebutuhan mereka. Selain itu juga dengan memberikan modal kebutuhan mereka. Selain itu juga dengan memberikan modal kepada mereka yang mempunyai keahlian dalam sesuatu sehingga dapat meneruskan kegiatan profesi karena mereka tidak mempunyai modal tersebut. Baik fakir miskin maupun yang mempunyai keahlian tetapi tidak memiliki modal, mereka ini diberikan sebagian harta zakat untuk memberdayakan mereka sehingga mereka dapat memenuhi kebutuhan mereka sendiri. Ini adalah suatu bentuk peran serta yang baik dari harta zakat. Tentang hal ini, Imam Nawawi mengatakan di dalam al-Majmu', dari perkataan mayoritas ulama mazhab Syafi'i. Mereka mengatakan bahwa sesuai dengan kebiasaan, orang yang mempunyai profesi tertentu diberikan sesuatu dari harta zakat, dengan maksud agar mereka menggunakannya untuk membeli alat-alat yang mendukung profesionalismenya, baik sedikit maupun banyak. Dengan demikian mereka mampu memenuhi kebutuhan hidup. Pemberian ini berbeda sesuai dengan perbedaan profesi, negara, waktu dan kepribadian masing-masing.

2. Pemberdayaan sebagian kelompok yang berhak atas harta zakat, adalah para fakir. Dengan memberikan sejumlah harta untuk memenuhi kebutuhan hidup mereka dan

${ }^{21}$ Tim Penyusun, Pedoman Zakat (Jakarta: Direktorat Pemberdayaan Zakat, 2006), 241.

${ }^{22}$ Abdul Al Hamid Mahmud Al Ba’ly, Ekonomi Zakat (Jakarta: Raja Grafindo Persada, 2006), 84. 
memberdayakan mereka yang memang tidak memiliki keahlian apapun, baik kerajinan maupun perdagangan. Tentang hal ini Syamsuddin al-Ramly mengatakan di dalam Sharh al-Minhāj al-Nawāwi bahwa jika para fakir miskin belum mendapatkan pekerjaan sebagai penunjang hidup mereka, baik dengan profesi maupun dengan berdagang, mereka diberikan bagian dari zakat secukupnya sesuai kebutuhan hidup dinegara mereka tinggal dan selama mereka hidup. Karena maksud dari pemberian tersebut hanyalah untuk memenuhi kebutuhan mereka yang belum terpenuhi. Jika umur mereka masih berlanjut, maka zakat diberikan tahun demi tahun. Akan tetapi, bukan berarti memberikan mereka seperti gaji dari hasil kerja, melainkan memberikan mereka sejumlah uang yang dapat digunakan untuk membeli rumah, yang kemudian mereka gunakan sebagai tempat kerja, yang akhirnya, dapat terlepas dari ketergantungan terhadap harta zakat. Sedangkan pendapat Imam Ahmad menyerupai pendapat jumhur al- 'ulama mazhab Syafi'i yang menyatakan bahwa fakir miskin boleh mengambil sesuai kebutuhan dari harta zakat secara terus menerus, baik untuk perdagangan mereka maupun ala-alat yang mendukung profesi mereka. Dalam kitab Ghāyah al-Muntahā wa Sharhuhū tertulis bahwa mereka yang memiliki profesi diberikan sejumlah harta dari zakat sesuai kebutuhan untuk membeli alat-alat pendukung profesi tersebut. Mereka yang berdagang diberikan modal usaha. Sedangkan selain yang dua tersebut di atas, mereka adalah para fakir miskin. Mereka diberikan sejumlah harta untuk menutupi kebutuhan hidup yang belum terpenuhi.

3. Pemberdayaan sebagian kelompok yang berhak akan harta zakat, yang memiliki penghasilan baru dengan ketidakmampuan mereka. Mereka adalah pegawai zakat dan para muallaf.

4. Pemberdayaan sebagian kelompok yang berhak akan harta zakat untuk mewujudkan arti dan maksud sebenarnya dari zakat selain mereka yang disebutkan di atas. Di antaranya adalah hamba sahaya, mereka yang di jalan Allah, ibn sabil dan mereka yang mempunyai banyak hutang. Mereka yang berperang di jalan Allah dan orang yang mempunyai banyak hutang untuk kepentingan yang berpiutang, walaupun kaya tetap diberikan sebagian harta zakat kepada mereka. Akan tetapi, pemberian ini diterima dengan pengawasan dan harus sesuai dengan tujuan diberikannya zakat. Jika tidak, mereka harus menggantinya dan jika mereka menggunakannya kemudian mendapat keuntungan, maka semua harta zakat dan keuntungan tersebut wajib dikembalikan.

Undang-Undang No. 38 tahun 1999 tentang pengelolaan zakat BAB I pasal I ayat 4 menyebutkan bahwa mustahiq adalah orang atau badan yang berhak menerima zakat, yaitu: ${ }^{23}$ fakir, miskin, 'àmil atau pengurus zakat, muallaf, riqab (budak), ghärimin (orang yang berhutang), fi sabilillah, dan ibn sabil.

\section{Badan Amil Zakat Nasional}

Badan Amil Zakat Nasional dibentuk oleh pemerintah untuk melaksanakan pengelolaan zakat secara nasional. Badan Amil Zakat Nasional merupakan lembaga pemerintah nonstruktural yang bersifat mandiri dan bertanggung jawab kepada Presiden melalui Menteri.

\footnotetext{
${ }^{23}$ Tim Penyusun, Fiqh Zakat (Bidang Haji Zakat dan Waqaf Kantor Wilayah Kementrian Agama Profinsi Jawa Timur, 2011), 85 .
} 
Dalam melaksanakan tugas Badan Amil Zakat Nasional menyelenggarakan fungsi perencanaan, pelaksanaan, pengendalian dan pelaporan pengumpulan, pendistribusian dan pendayagunaan zakat. Badan Amil Zakat Nasional juga dapat bekerjasama dengan pihak terkait sesuai dengan ketentuan peraturan perundang-undangan ${ }^{24}$.

Dalam rangka pelaksanaan pengelolaan zakat pada tingkat provinsi dan kabupaten atau kota dibentuk Badan Amil Zakat Nasional provinsi dan Badan Amil Zakat Nasional kabupaten atau kota. Badan Amil Zakat Nasional provinsi dibentuk oleh Menteri atas usul Gubernur setelah mendapat pertimbangan Badan Amil Zakat Nasional. Badan Amil Zakat Nasional kabupaten atau kota dibentuk oleh Menteri atau pejabat yang ditunjuk atas usul Bupati atau Walikota setelah mendapat pertimbangan Badan Amil Zakat Nasional.

Dalam hal Gubernur atau Bupati atau Walikota tidak mengusulkan pembentukan Badan Amil Zakat Nasional provinsi atau Badan Amil Zakat Nasional kabupaten atau kota, Menteri atau Pejabat yang ditunjuk dapat membentuk Badan Amil Zakat Nasional provinsi atau Badan Amil Zakat Nasional kabupaten atau kota setelah mendapat pertimbangan Badan Amil Zakat Nasional. Badan Amil Zakat Nasional provinsi dan Badan Amil Zakat Nasional kabupaten atau kota melaksanakan tugas dan fungsi Badan Amil Zakat Nasional di provinsi atau Badan Amil Zakat Nasional kabupaten atau kota masing-masing. ${ }^{25}$

\section{Pendayagunaan Zakat Produktif Pada BAZNAS Kabupaten Lumajang}

Sistem pendayagunaan zakat yang diterapkan Badan Amil Zakat Nasional (BAZNAS) Kabupaten Lumajang adalah pendayagunaan yang bersifat konsumtif dan pendayagunaan yang bersifat produktif. Dalam hal yang sifatnya konsumtif, BAZNAS Kabupaten Lumajang memberikan bantuan yang sekali pakai saja sudah habis. Sedangkan dalam hal yang sifatnya produktif, BAZNAS Kabupaten Lumajang memberikan bantuan seperti dana bergulir, beasiswa, alat-alat produktif, bantuan modal usaha dan lain-lain.

Dengan adanya pendayagunaan yang dilakukan oleh BAZNAS Kabupaten Lumajang maka sebagian masyarakat yang sudah dibantu oleh BAZNAS berupa pinjaman dana untuk usaha yang produktif yang meningkatkan penghasilan sudah berjalan sangat baik dan membantu ekonomi masyarakat menengah ke bawah.

Hasil dari penerapan pendayagunaan secara teori maupun secara praktik yang dilakukan oleh BAZNAS Kabupaten Lumajang sangat sesuai. Dari hasil penerapan tersebut sangat dirasakan manfaatnya oleh kalangan yang memang membutuhkannya (mustahiq).

Yang menarik pada BAZNAS Kabupaten Lumajang adalah bentuk zakat yang menggunakan sistem kerelaan, yaitu memberikan zakat dengan suka rela, tanpa suatu paksaan apapun. Karena jika muzakki merasa keberatan dengan sebagian harta yang sebenarnya wajib untuk dikeluarkan oleh mereka, dikhawatirkan zakat yang diberikan tidak berkah. Hal tersebut sangat berpengaruh terhadap perkembangan BAZNAS Kabupaten Lumajang dalam meningkatkan jumlah muzakki agar menyalurkan dana zakatnya melalui BAZNAS Kabupaten Lumajang. Hal ini terjadi karena tingkat kesadaran masing-masing muzakki untuk menunaikan dana zakatnya itu tidak sama. Justru ada sebagian dari muzakki yang masih belum menyadari akan arti penting dari zakat itu sendiri. Mereka tidak menyadari bahwa

\footnotetext{
${ }^{24}$ Tim Penyusun, Manajemen Pengelolaan Zakat (Jakarta: Kementerian Agama RI, 2012), 27.

${ }^{25}$ Ibid., 29.
} 
zakat itu adalah suatu kewajiban mereka untuk memberikan sebagian hartanya kepada mereka para mustahiq.

\section{Pemberdayaan Mustahiq pada BAZNAS Kabupaten Lumajang}

Pemberdayaan yang berkaitan dengan penyampaian kepemilikan harta zakat kepada mereka yang berhak terbagi ke empat bagian, yaitu: ${ }^{26}$

1. Pemberdayaan sebagian dari kelompok yang berhak akan harta zakat, misalnya fakir miskin, yaitu dengan memberikan harta zakat kepada mereka sehinga dapat memenuhi kebutuhan mereka. Selain itu juga dengan memberikan modal kebutuhan mereka.

2. Pemberdayaan sebagian kelompok yang berhak atas harta zakat, adalah para fakir. Dengan memberikan sejumlah harta untuk memenuhi kebutuhan hidup mereka dan memberdayakan mereka yang memang tidak memiliki keahlian apapun, baik kerajinan maupun perdagangan.

3. Pemberdayaan sebagian kelompok yang berhak akan harta zakat, yang memiliki penghasilan baru dengan ketidakmampuan mereka. Mereka adalah pegawai zakat dan para muallaf.

4. Pemberdayaan sebagian kelompok yang berhak akan harta zakat untuk mewujudkan arti dan maksud sebenarnya dari zakat selain mereka yang disebutkan di atas. Di antaranya adalah hamba sahaya, mereka yang di jalan Allah, ibn sabil dan mereka yang mempunyai banyak hutang. Mereka yang berperang di jalan Allah dan orang yang mempunyai banyak hutang untuk kepentingan yang berpiutang, walaupun kaya tetap diberikan sebagian harta zakat kepada mereka. Akan tetapi, pemberian ini diterima dengan pengawasan dan harus sesuai dengan tujuan diberikannya zakat. Jika tidak, mereka harus menggantinya dan jika mereka menggunakannya kemudian mendapat keuntungan, maka semua harta zakat dan keuntungan tersebut wajib dikembalikan.

Pola distribusi zakat produktif yang dikembangkan pada umumnya mengambil skema qard al-ḥasan. Yaitu salah satu bentuk pinjaman yang menetapkan tidak adanya tingkat pengembalian tertentu dari pokok pinjaman. Namun bila ternyata si peminjam dana tersebut tidak mampu mengembalikan pokok tersebut, maka hukum zakat mengidentifikasikan bahwa si peminjam tersebut tidak dapat dituntut atas ketidakmampuannya. Karena dana tersebut adalah hak mereka ${ }^{27}$.

Ada juga penyaluran dana zakat produktif yang memanfaatkan skema mudärabah. Lembaga LAZIS membuat inovasi di mana lembaga amil zakat tersebut berlaku sebagai investor (mudārib) yang menginvestasikan dana hasil pengumpulan ZIS kepada mustahiq sendiri, sebagai peminjam dana yang dituntut tingkat pengembalian tertentu khusus bagi para pedagang kecil di pasar tradisional, dengan angsuran pinjaman dan tingkat pengembalian dibayarkan per hari. Antara pola mudärabah dan qard al-hasan hampir sama. Namun yang membedakan adalah apabila usaha tersebut untung, maka mustahiq mengambil sejumlah persen laba dan sejumlah persen dikembalikan kepada BAZ berikut modalnya. BAZ menerima modal kembali berikut persentase keuntungan usaha. ${ }^{28}$

\footnotetext{
${ }^{26}$ Abdul Al Hamid Mahmud Al Ba'ly. Ekonomi Zakat, 84.

${ }^{27}$ M. Arief Mufraini, Akuntansi dan Menejemen Zakat, 165.

${ }^{28}$ Ibid., 168.
} 
Sistem pemberdayaan yang diterapkan oleh Badan Amil Zakat Nasional (BAZNAS) Kabupaten Lumajang adalah memberdayakan 8 așnaff yang telah ada ketentuannya, yaitu fakir, miskin, 'ämil, muallaf, riqab (budak), ghärimin (orang yang berhutang), fĩ sabilillah dan ibn sabil. Tujuan dari pemberdayaan adalah agar mereka para mustahiq bisa meningkatkan taraf kehidupan mereka untuk menuju yang lebih baik dan tidak ketergantungan dengan dana zakat.

Dalam hal penyaluran dana zakat, BAZNAS Kabupaten Lumajang menerapkan pemberdayaan yang bersifat produktif dan konsumtif. Pada pemberdayaan yang bersifat produktif, BAZNAS Kabupaten Lumajang melakukan pinjaman modal usaha produktif, hanya menggunakan akad qard al-ḥasan saja. Sedangkan pada pemberdayaan yang bersifat konsumtif, BAZNAS Kabupaten Lumajang hanya memberikan bantuannya kepada mereka yang benar-benar tidak memiliki penghasilan dan lemah. Seperti memberikan bantuan yang berupa bedah rumah dan lain-lain.

\section{Kesimpulan}

Berdasarkan hasil penelitian di atas, maka dapat disimpulkan bahwa pendayagunaan dana zakat produktif merupakan salah satu proses yang dilakukan oleh Badan Amil Zakat Nasional (BAZNAS) Kabupaten Lumajang untuk memandirikan para mustahiq agar mereka dapat meningkatkan taraf hidup mereka dan bisa menjadi muzakki seperti yang telah menjadi visi BAZNAS Kabupaten Lumajang. Bentuk pendayagunaan dana zakat terhadap pemberdayaan mustahiq pada BAZNAS Kabupaten Lumajang dibagi menjadi dua, yaitu pemberdayaan yang bersifat konsumtif dan produktif. Pemberdayaan konsumtif yaitu pemberian dana yang langsung dapat dikonsumsi oleh mustahiq. Sedangkan produktif yaitu pemberian modal di dalam meningkatkan usaha, baik berupa dana maupun pemberian berupa alat kerja. Hal yang paling efektif di dalam memberdayakan para mustahiq ini adalah memberdayakan dengan menggunakan dana zakat produktif yang telah banyak dirasakan manfaatnya oleh para mustahiq.

\section{Daftar Rujukan}

Arikunto, Suharsimi. Prosedur Penelitian Suatu Pendekatan Praktik. Jakarta: Bina Aksara, 2002.

Ash Shiddieqy, Muhammad Hasbi. Pedoman Zakat. Semarang: Pustaka Rizki Putra, 2006.

Djuanda, Gustian, Dkk. Pelaporan Zakat Pengurang Pajak Penghasilan. Jakarta: Rajawali Pers, 2006.

Fakhruddin. Fiqih dan Manajemen Zakat di Indonesia. Yogyakarta: UIN-Malang Press, 2008. Hadi, Muhammad. Problematika Zakat Profesi dan Solusinya. Yogyakarta: Pustaka Pelajar, 2010.

Hasan, M. Ali. Zakat dan Infak. Jakarta: Kencana Prenada Media Group, 2006.

Hasby, Al Furqon. 125 Masalah Zakat. Solo: Tiga Serangkai Pustaka Mandiri, 2008.

Huda, Husnul. "Fikih Pengelolaan Produktif Sebagai Upaya Pengembangan Sumber Daya Mustahiq". Tesis--Institut Agama Islam Negeri (IAIN) Walisongo, Semarang, 2012.

Khasanah, Umrotul. Manajemen Zakat Modern. Malang: UIN-Maliki Press, 2010.

Mahmud Al Ba'ly, Abdul Al Hamid. Ekonomi Zakat. Jakarta: Raja Gravindo Persada, 2006. 
Milles, Matthew B. dan A. Micheal Huberman. Analisis Data Kualitatif, Terj. Tjejep Rohendi. Jakarta: Universitas Indonesia Press, 1992.

Mufraini, M. Arief. Akuntansi dan Menejemen Zakat. Jakarta: Kencana Predana Media Group, 2006.

Muhammad, Sahri. Mekanisme Zakat dan Permodalan Masyarakat Miskin. t.tp: Bahtera Press, 2006.

Ridwan, Muhammad. Manajemen Baitul Maal Wa Tamwil (BMT). Yogyakarta: UII Press, 2004.

Rofiq, Ahmad. Komplikasi Zakat. Semarang: Balai Penelitian dan Pengembangan Agama Semarang, 2010.

Sabiq, Sayyid. Fikih Sunnah, Terj. Mahyudin Syaf. Bandung: Al Ma'arif, t,th.

Sudjana, Nana. Penelitian Dan Penilaian Pendidikan Bandung: Sinar Baru Algesindo, 2001.

Tim penyusun. Pedoman Zakat 9 seri. Jakarta: Proyek Peningkatan Saran Keagamaan Islam, Zakat dan Waqaf, 1997.

Tim Penyusun. Pedoman Zakat. Jakarta: Direktorat Pemberdayaan Zakat, 2006.

Tim Penyusun. Kamus Populer Keuangan dan Ekonomi Syari'ah. Jakarta: Pusat Komunikasi Ekonomi Syariah, 2007.

Tim Penyusun. Fiqh Zakat. Bidang Haji Zakat dan Waqaf Kantor Wilayah Kementrian Agama Profinsi Jawa Timur, 2011.

Tim Penyusun. Manajemen Pengelolaan Zakat. Jakarta: Kementrian Agama RI, 2012.

Tim Penyusun. Himpunan Peraturan Perundangan Pengelolaan Zakat. Lumajang: BAZNAS Kabupaten Lumajang, t.th. 